\title{
Discrimination
}

\section{Pakistan: the right to marry}

\section{by Mr Justice Tassaduq Hussain Jilani}

\section{$\mathrm{T}$} he UN Convention on the Elimination of All Forms of Discrimination against Women (CEDAW), adopted in 1979, was the culmination of the age-old odyssey to establish equality between men and women. Its proponents were conscious of the toll, the sufferings and wages of the gender bias. They therefore made a global call for a collective struggle to carve out a just social order and to evolve a 'newer' world. The spirit of the convention, in the words of Tennyson, was:

\section{'The long day wanes; the slow moon climbs; the deep Moans round with many voices. Come, my friends; \\ 'Tis not too late to seek a newer world.}

(Alfred, Lord Tennyson, Ulysses)

The moans were replaced by a new resolve and determination to pursue the goals set out in the 'Magna Carta' of women's rights in various spheres of life. On the issue of the right to marry, art. 16 of the CEDAW mandated inter alia.as follows:

'I. States parties shall take all appropriate measures to eliminate discrimination against women in all matters relating to marriage and family relations and in particular shall ensure, on a basis of equality of men and women:

(a) the same right to enter into marriage;

(b) the same right freely to choose a spouse and to enter into marriage only with their free and full consent;

(c) the same right[s] and responsibilities during marriage and at its dissolution.'

\section{EAST $~$ WEST}

The right of an adult woman to marry a person of her choice is well recognised in the civilised world today. In the West a father reacting to his adult daughter's decision to marry a person against his wishes would only be found in some Victorian drama or a Shakespearian tragedy. In the East, however, instances are not lacking where the objections of parents and elders lead to violence and killing in the name of 'honour'.

The right of an adult woman to marry a person of her choice is well recognised in the civilised world today. In the West a father reacting to his adult daughter's decision to marry a person against his wishes woukl only be found in some Victorian drama or a Shakespearian tragedy. In the East, however, instances are not lacking where the objections of parents and elders lead to violence and killing in the name of 'honour'. The denial of the right to marry a person of choice is one of the major reasons for violence against young women in some thirdworld countries. I would like to share our experience in Pakistan. The issues that I propose to highlight are the following: (1) the right to marry: sociological and historical perspective;
(2) the right of marriage in Islam; and

(3) the constitutional provisions and role of the courts in Pakistan.

\section{SOCIO-HISTORICAL PERSPECTIVE}

The institution of marriage and the right to marry as we understand them today are the result of a long process of evolution. As far back as the memory of history can perceive the freedom of the individual in choosing a mate was strictly limited by social need and a written or an unwritten code. Societies regulated this domain and laid down parameters within which it was permissible to marry. The first sexual taboos seem to have aimed at preventing the mating of parents and children, then the brothers and sisters and gradually the prohibitions spread to exogamy (prohibition to marry within the tribe) and endogamy (marrying someone from within one's own tribe or group).

Wealth and property have played an important role in marriage. Be it the Occident or the Orient, the girl was mated by her parents, who mostly kept a proprietary interest in view while taking such a decision. However, with the spread of education and the economic independence of men and women, the 'romantic love and choice marriage' brought about a social sea change in the institution of marriage. In the West this has led to a complete metamorphosis, and the right of an adult girl to marry a person of her own choice stands recognized both socially and legally. In the East, however, the subjective perception of religion, social, feudal and tribal taboos regulate the exercise of this right in varying degrees.

Marriages in our part of the world, in the great majority of cases, are arranged by parents. The prospective bride and bridegroom do not meet, there is no courtship, and in some cases they see each other for the first time on the wedding night. This may appear shocking to an observer from the West but this culture is the logical consequence of our socio-economic conditions. The family is still the dominating institution. Crucial decisions regarding the marriage of girls are made mostly by the head of the family and the girl is persuaded to accept the proposal. Notwithstanding some grey areas, these arranged marriages have several advantages: in a segregated society where boys and girls normally cannot meet, the practice of arranged marriages ensures that the interests of both the parties are pursued more meaningfully and with mature advice. Seventy per cent of the girls here do not even go to primary school and therefore are neither socially nor economically independent. The family's role in these circumstances and in most of the cases is a welcome relief. However, in certain parts of Pakistan and in some families the social taboos or tribal prejudices overwhelm the parental authority to such an extent that it operates to the detriment of the women. This dilemma has been acknowledged in the Pakistan National Report submitted to the Fourth World Conference on Women in September 1995 in Beijing, in which it was stated that: 
'The persistence of tribal and feudal structures has perpetuated the culture of stereotyped roles for girls and women. The socialization process creates gender differences from childhood, and together with the early age of marriage, early and frequent pregnancies, large family size, and the perception of the limited reproductive and domestic roles of women places restrictions on their mobility and participation in the productive process and decision-making.'

Given the socio-economic milieu that women have to live in, it is no wonder that girls are given in marriage without their consent and in a few cases even sold in marriage. The sporadic incidents of violence that we witness are symptomatic of a girl rebelling against these taboos to establish her right to marry a person of her choice.

\section{THE RIGHT OF MARRIAGE IN ISLAM}

Although there are clear commands of the Holy Prophet Muhammad (Peace Be Upon Him) regarding the requirement for a girl's consent to marriage, this issue has been the subject of controversy among the Muslim jurists. There are broadly speaking five schools of jurists in Islam. These are:

- Maliki

- Hambali

- Hanafi

- Sha'afi, and

- Jafri.

There is a broad consensus among Muslim jurists that a Muslim woman needs a wali (guardian), usually a father, to contract marriage. However, there are conflicting views on the extent of the wali's authority in matters of marriage. Some jurists are of the view that a marriage without a wali's consent is void while others regard the wali's role as that of a guide and hold that the marriage of an adult woman can be performed even without the consent of her wali. The concept of 'Ijtihad' is a recognized mode of reasoning whereby, in the event of lack of any specific command over an issue, the matter is resolved in the light of the Quranic injunctions. The Superior Courts in Pakistan have played a pivotal role in interpreting various concepts of Islamic law.

Today the case law on this issue is mostly in favour of the view that a young adult woman can enter into marriage without the consent of her wali. Three judgments of the Federal Shariat Court of Pakistan, i.e. Muhammad Imtiaz \& Anor v The State PLD 1981 FSC 308, Arif Hussain \& Azra Perveen v The State PLD 1982 FSC 42, Muhammad Ramzan v The State PLD 1984 FSC 93 and two judgments of the Lahore High Court, i.e. Hafiz Abdul Waheed v Miss Asma Jahangir \& Anor PLD 1997 Lahore 301 and Mst. Humaira Mehmood v SHO North Cantt. Lahore \& Ors PLJ 1999 Lahore 1474 and 1999 Pakistan Current Criminal Rulings 542 Lahore, would be relevant in this context.

Conscious of the social taboos, and with a view to highlighting the importance of consent in Islam, some of the Muslim countries have codified the requirement of a girl's consent to marriage. In Tunisia the law mandates that consent of both the spouses is essential in marriage. Yemeni law declares that a marriage where consent is obtained through coercion would be void. In Syria, which is a predominantly Hanafi State, the Syrian Personal Status Code limits a wali's ability unfairly to block, delay 'or cause the avoidance of marriage of a girl who has reached the age of majority. In Morocco the Personal Status Code prohibits a wali from forcing a female into marriage, whether she is a virgin or otherwise, provided she has attained the age of majority (Aziza Y Al-Hibra, Marriage \& Divorce, Legal Foundations).

\section{IJTIHAD}

The concept of 'Ijtihad' is a recognized mode of reasoning whereby, in the event of lack of any specific command over an issue, the matter is resolved in the light of the Quranic injunctions. The Superior Courts in Pakistan have played a pivotal role in interpreting various concepts of Islamic law.

The demand to grant equal rights to women in matters of marriage is enshrined in the Cairo Declaration on Human Rights in Islam, agreed at a conference attended by representatives of all the Muslim countries on 5 August, 1990 (Edward Lawson, Encyclopedia of Human Rights, 2nd edn, at p. 176). Article 5 of this declaration mandates as follows:

(a) The family is the foundation of society, and marriage is the basis of its formation. Men and women have the right to marriage, and no restrictions stemming from race, colour or nationality shall prevent them from enjoying this right.

(b) Society and the State shall remove all obstacles to marriage and shall facilitate marital procedure. They shall ensure family protection and welfare.'

\section{CONSTITUTIONAL PROVISIONS AND ROLE OF THE COURTS}

The Constitution of the Islamic Republic of Pakistan guarantees equal rights to women. It would be pertinent to refer to some of the important provisions highlighting the equality of men and women. Article 25(2) provides that 'there shall be no discrimination on the basis of sex alone'. Article 25(3) reiterates that 'nothing in this Article shall prevent the State from making any special provision for the protection of women and children'. Article 35 provides that 'the State shall protect the marriage, the family, the mother and the child'.

These provisions would indicate that the Constitution of the Islamic Republic of Pakistan envisages complete equality between men and women and mandates that the State shall provide protection to marriage. However, a lot was left to the Legislature. Unlike the legislation made in some other Muslim countries, the right of an adult woman to marry a person of her choice has not been specifically provided for in any law in Pakistan. Perhaps it was taken for granted, or it may be on account of the social and tribal taboos or a myopic perception of religion that this was never a priority issue with the law makers. The void has, however, been filled by the courts.

The right of an adult woman to marry a person of her choice has now been well recognized in judicial pronouncements in Pakistan. Barring one or two judgments given by the High Court, the preponderance of case law is in favour of the view that in Islam the permission of a guardian is not required if an adult woman wants to marry a person of her own choice. The permission of a guardian, or guidance, may be socially desirable but it has been held that it is not mandatory in Islam. The courts 
have maintained a progressive and liberal profile and thereby have also curbed the misuse of the Hudood Laws. In Muhammad Imtiaz's case, a young woman aged 18 married of her own choice, a criminal case was registered against the girl and her husband, on the statement of her father, alleging abduction, theft and adultery and the learned trial court convicted both of them, notwithstanding the defence plea taken by the girl that the case was false and that the father had had the case registered as he was not happy about the marriage. The matter went up in appeal before the Federal Shariat Court, and after a detailed discussion on the concept of the right to marry in Islam the court set aside the conviction and held that a girl who had reached the age of majority had a right to marry and that the consent of the guardian was not essential.

In Arif Hussain's case, again a father had a criminal case registered against his daughter on the allegation that she had been abducted by 'A' one and a half years previously, that they were leading a life of adultery and that out of the alleged illicit liaison they had given birth to a baby girl. The case was tried and valid marriage was taken as a plea in defence. The court, however, convicted both of them and sentenced them to ten years RI and a fine by holding that they had no written proof of marriage to support their plea. This judgment was set aside by the Federal Shariat Court on appeal and it reiterated a very important principle of Islamic jurisprudence on validity of marriage, i.e. it held that acknowledgement by a man and a woman that they are husband and wife raises a presumption of truth regarding the validity of the marriage and no written proof or registration is required.

The ratio reiterated in these two judgments was affirmed in yet another judgment, Muhammad Ramzan's case.

In a recent case in the Lahore High Court (Humaira's case), which I was called upon to decide, the dilemma of a girl marrying against the wishes of her parents came up in a rather poignant manner. It is a painful study and illustrates how far a father can go to assert his authority over the question of a young adult daughter's marriage. The facts of this case are that a young woman aged 28, the only daughter of a sitting member of the Punjab Provincial Assembly, having a rural background but urbanized on account of having studied in a liberal institution, fell in love with a boy and wanted to marry him. This marriage was resisted by the parents, particularly the father, as he wanted to give her hand in marriage to his nephew. This was to be an exchange marriage. The girl ' $\mathrm{H}$ ' secretly married the person of her choice ' $M$ ', but did not join him and made efforts to persuade her parents to accept the marriage. The parents rejected it and staged a forced marriage with her cousin (whose sister was already in their house as a daughter-in-law). She left the house and wanted to flee abroad with her husband, but on account of her father's influence as an MPA a criminal case was registered, she was arrested at the airport, openly dragged and beaten. She was granted bail by the High Court, but the bail order was not honoured and the police attempted to hand over her custody to her brother and father, whereupon a petition was filed on her behalf by women activists alleging that she would be killed on account of so-called 'family honour'. Following a direction to the Inspector General of Punjab Police the girl was produced before the court and her statement was recorded. The father controverted her claim that she was already married to ' $\mathrm{M}$ ' and produced a video cassette of the arranged marriage with his nephew. The issues mooted before the court in this case were:

(1) can a girl who has reached the age of majority can marry a man of her own choice and against the wishes of her guardian/father?

(2) what is the legal effect of the second marriage, which according to the girl was forced upon her by the father although, admittedly, she had not joined her second husband?

(3) could the court sitting in the constitutional jurisdiction enter into the factual inquiry qua the conflicting claims of marriages or should this be left to the civil court of plenary jurisdiction?

In a detailed judgment the right of a girl of adult age to marry a person of her choice was upheld. With reference to Islamic law, the second marriage was held to be void ab initio; it was observed that in the video the girl was sobbing and the bridegroom wore a gloomy expression that reflected her lack of consent. The court observed that, in a situation where the criminal case was false, the official record indicated that the second marriage was arranged by the father without her consent at a later date, and that she was facing a death threat, the court could enter into a factual inquiry and give a tentative finding of fact on conflicting claims of marriage. Sending that matter to the civil court would have prolonged the agony of the young girl. This case acquired public importance both nationally and internationally and the positive sign is that, notwithstanding the social perception qua the role of the guardian and the father in matters relating to the marriage of young daughters, the judgment had wide acceptance and all the national dailies highlighted in their editorials the need for a change in attitudes and social mores with regard to the rights of young women in Pakistan. In its editorial of 20 February 1999, the English newspaper Dawn commented:

\section{CAIRO DECLARATION}

The demand to grant equal rights to women in matters of marriage is enshrined in the Cairo Declaration on Human Rights in Islam, agreed at a conference attended by representatives of all the Muslim countries on 5 August, 1990

'Women activists, human rights lawyers and all enlightened people will welcome the judgment of the Lahore High Court in the Humaira/Mahmood Butt case. Although in legal terms this was a case of establishing the validity of a nikahnama and its implications for the couple under the Hudood laws, fundamental principles were at stake. One was the importance of consent of the two parties entering into a marriage contract. (Humaira had married Mahmood against the wishes of her father who forced her to enter into false matrimonial arrangement with a cousin). Another was the need to recognize the right of an adult woman as an independent entity and not a chattel of a male member of her. family. There was also the principle of the police protection to which citizens are entitled under the law and their right not to have mala fide criminal cases registered against them. Mercifully, the LHC has upheld all of these.

There are two vital social/political issues which have been thrown into focus by this case. One is that of safeguarding the institution of the family in a patriarchal society like ours. There is no right-minded 
person who would not uphold the sanctity of the family. But the need is to introduce the concept of human rights and women's rights in intrafamily relationships. Those who try to subjugate women on the plea of observing Islamic laws need to be educated in the rights which have been granted to women by the sharia. Marriage in Islam is a contract whose validity depends on the freely given consent of the parties concerned. Quite often the woman's consent is taken for granted as the freedom of contract is violated through coercion or fraud, with her father or brother giving her away in marriage against her will.'

Similarly, the daily paper The News titled its editorial as 'Changing Norms' and said:

'The Lahore High Court Thursday dismissed a Hudood case against the daughter of a Punjabi MPA, Humaira Butt, and her husband, Mahmood Butt, by validating the couple's marriage of their own free will, ending another of our modern day folk-lores, which could now be part of a bigger social change

Of course, the role of human rights groups and some individuals dedicated to the cause of female emancipation in advocating such cases is admirable. The media too, by and large, refuse to sit on the fence and, as happened in the Humaira Mahmood episode, coverage of police actions brought a number of facts to public knowledge. It has been seen that fables of threatened couples on the run always evoke a wave of general sympathy in what is believed to be a highly repressive, genderbiased society. The $L H C$ verdict reinforces this propitious trend by granting legal and religious cover to changing norms replacing an untenable medieval ethos.'

\section{CASE LAW}

The right of an adult woman to marry a person of her choice has now been well recognized in judicial pronouncements in Pakistan. Barring one or two judgments given by the High Court, the preponderance of case law is in favour of the view that in Islam the permission of a guardian is not required if an adult woman wants to marry a person of her own choice. The permission of a guardian, or guidance, may be socially desirable but it has been held that it is not mandatory in Islam.

The Nation, in its editorial dated 22 February 1999, observed:

'The decision of the Lahore High Court to hold prima facie valid the love marriage of Humaira to Mahmood Butt brings to an end at least for the time being the painful uncertainty and suffering of the couple. While an Intra Court Appeal by the parents may lie ahead as of now it is a well deserved and an encouraging victory for the advocates of women's rights and indeed women themselves who notwithstanding the progress achieved towards their freedom as a result of socio-economic compulsions of today, the introduction of modern trends in the country and the endeavours of enlightened groups remain in bondage of their parents especially when faced with the choice of their spouses..

While Islam grants full freedom of choice to adult men and women to choose their future spouses the feudal customs which hold sway in our society virtually leave women with no other option than to accept the husbands chosen by their parents. The court's judgment it is hoped will go a long way in convincing the parents who are slave to this un-Islamic custom to take into account the wishes of their daughters about choosing their future's husbands. It defies all logic to believe that a man or a woman who has to spend a lifetime with his or her spouse should have no say in the matter. Those who are struggling to ensure the grant of due rights and freedom to our unfortunate women deserve our full support. The court has rightly observed that "let there be no contradiction in our thoughts and actions. Male chauvinism, feudal bias and compulsion of a conceited ego should not be confused with Islamic values". It warned that "an enlightened approach is called for otherwise an obscurantism in this field may break the social fabric".'

An appeal was filed against this judgment but has been dismissed as withdrawn and the judgment has attained finality.

Humaira's case is one of the thousands of cases where women have raised their voice of dissent against exchange marriage or against an incompatible proposition and have made their own choice.

While upholding the girl's right to marry a person of her choice, the courts in Pakistan have never minimised the importance of the family; it is believed that it is a natural and divine institution which delineates the respective spheres of the father and mother, the husband and wife, and the brother and sister. We would like to protect this institution. But at the same time male chauvinism, conceited egos and the feudal/tribal bias should not be allowed to hold sway at the cost of a woman's right to have a life partner of her choice. The judiciary, through its pronouncements, endeavours on the one hand to instil the serenity to comprehend the winds of change in those who are jealous of their right as guardians to decide about their ward's marriage and, on the other, to give consideration to the maturity of young women to make an informed choice.

Social mores and practices change with the dynamics of time. Today in Pakistan we are witnessing a change which is concomitant with industrial revolution, the spread of education and the dawn of the age of reason. In a society steeped in tradition conflicting social responses are natural. At times the reaction is oppressive and at others it is violent. Attitudes, practices, prejudices and taboos take time to change, but I do see a big social change in the offing. Academicians, the media and the non-governmental organisations (NGOs) are all contributing to this change, but the Superior Courts are taking the lead in interpreting the tenets of Islam qua issues relating to marriage in a more dynamic, liberal and progressive manner. This court profile is in consonance with our religious ethos, our constitutional commitment on gender equality and accords with the underlying theme of CEDAW.

\section{Mr Justice Tassaduq Hussain Jilani}

Judge, Lahore High Court, Lahore, Pakistan

This article is based on an address given in 1999 to commemorate the 20th anniversary of the Convention on the Elimination of All Forms of Discrimination against Women (CEDAW). 